\title{
Clinicians' views on learning in brain injury rehabilitation
}

Citation for published version (APA):

Boosman, H., Visser-Meily, J. M. A., Winkens, I., \& van Heugten, C. M. (2013). Clinicians' views on learning in brain injury rehabilitation. Brain Injury, 27(6), 685-688.

https://doi.org/10.3109/02699052.2013.775504

Document status and date:

Published: 01/01/2013

DOI:

10.3109/02699052.2013.775504

Document Version:

Publisher's PDF, also known as Version of record

Document license:

Taverne

\section{Please check the document version of this publication:}

- A submitted manuscript is the version of the article upon submission and before peer-review. There can be important differences between the submitted version and the official published version of record.

People interested in the research are advised to contact the author for the final version of the publication, or visit the DOI to the publisher's website.

- The final author version and the galley proof are versions of the publication after peer review.

- The final published version features the final layout of the paper including the volume, issue and page numbers.

Link to publication

\footnotetext{
General rights rights.

- You may freely distribute the URL identifying the publication in the public portal. please follow below link for the End User Agreement:

www.umlib.nl/taverne-license

Take down policy

If you believe that this document breaches copyright please contact us at:

repository@maastrichtuniversity.nl

providing details and we will investigate your claim.
}

Copyright and moral rights for the publications made accessible in the public portal are retained by the authors and/or other copyright owners and it is a condition of accessing publications that users recognise and abide by the legal requirements associated with these

- Users may download and print one copy of any publication from the public portal for the purpose of private study or research.

- You may not further distribute the material or use it for any profit-making activity or commercial gain

If the publication is distributed under the terms of Article $25 \mathrm{fa}$ of the Dutch Copyright Act, indicated by the "Taverne" license above, 


\title{
Brain Injury
}

\section{Clinicians' views on learning in brain injury rehabilitation}

\author{
H. Boosman, J. M. A. Visser-Meily, I. Winkens \& C. M. van Heugten
}

To cite this article: H. Boosman, J. M. A. Visser-Meily, I. Winkens \& C. M. van Heugten (2013) Clinicians' views on learning in brain injury rehabilitation, Brain Injury, 27:6, 685-688, DOI: 10.3109/02699052.2013.775504

To link to this article: https://doi.org/10.3109/02699052.2013.775504

\section{Published online: 23 Apr 2013.}

Submit your article to this journal $\sqsubset$

Џ Article views: 441

Q View related articles $\sqsubset$

Citing articles: 4 View citing articles 


\title{
Clinicians' views on learning in brain injury rehabilitation
}

\author{
H. Boosman 1, J. M. A. Visser-Meily ${ }^{1}$, I. Winkens², \& C. M. van Heugten ${ }^{2,3}$ \\ ${ }^{1}$ Rudolf Magnus Institute of Neuroscience and Center of Excellence for Rehabilitation Medicine, University Medical Center Utrecht and \\ De Hoogstraat Rehabilitation, Utrecht, The Netherlands, ${ }^{2}$ Department of Psychiatry and Neuropsychology, School for Mental Health and \\ Neuroscience, and ${ }^{3}$ Department of Neuropsychology and Psychopharmacology, Faculty of Psychology and Neuroscience, Maastricht University, \\ Maastricht, The Netherlands
}

\begin{abstract}
Primary objective: To determine clinicians' views on learning ability in brain injury rehabilitation. Research design: Online survey.

Methods and procedures: An online survey was sent to physicians, psychologists and therapists of three Dutch organizations for neuropsychology or rehabilitation. The survey enquired (1) whether clinicians take learning ability into account; (2) about factors influencing learning ability; and (3) about assessment tools used to assess learning ability.

Main outcomes and results: Thirty-seven physicians, 83 psychologists and 43 therapists completed the online survey. In total, $93 \%$ of respondents reported that they take learning ability into account when making a prognosis. The most frequently mentioned factors influencing learning ability were cognition, awareness of deficits and motivation. Learning ability was mainly determined by means of cognitive and memory tests and observations during therapy.

Conclusions: This study demonstrates that a patient's learning ability may be influenced by not only cognition but also by motivation and awareness of deficits. Structured and standardized assessment of these factors may be suggested for standard use in clinical practice. More research is needed about the influence these factors have on the learning process.
\end{abstract}

\section{Keywords}

Learning ability, neuropsychology, survey

\section{History}

Received 25 September 2012

Revised 1 February 2013

Accepted 7 February 2013

Published online 19 April 2013

\section{Introduction}

Rehabilitation can be described as an educational, problemsolving process [1]. Obviously, the objective of education is learning which is defined as the acquisition of new information [2]. During rehabilitation, patients re-learn old skills and learn new skills in order to optimize social participation and well-being [1]. The rate of learning influences the time needed to accomplish rehabilitation goals. This in turn affects the costs of care [3]. Although patients' learning ability is frequently discussed in brain injury rehabilitation practice, the current scientific literature provides little insight into this complex concept.

A patient's learning ability may be affected by brain injury sequelae. A factor that is commonly associated with learning ability is cognitive functioning and in particular memory functioning $[2,4]$. For instance, when using a verbal learning task, the presence of a learning curve with adequate delayed recall is said to reflect learning ability and consequently the potential to profit from rehabilitation [2, 4]. Solely considering the patient's cognitive or memory profile when estimating

Correspondence: C. M. van Heugten, Maastricht University, School for Mental Health and Neuroscience, Department of Psychiatry and Neuropsychology, PO Box 616, 6200 MD Maastricht, The Netherlands. Tel: 0031 433884091. Fax: 00314338840 92. E-mail: c.vanheugten@ maastrichtuniversity.nl the ability to learn raises the question as to whether it is fair to state that all patients with poor cognitive functioning have poor ability to learn during rehabilitation. In contrast, does the absence of (severe) cognitive impairments automatically imply adequate learning ability? Other factors may also influence the rehabilitation process. A previous study [5] suggested that the frequently observed cognitive, physical and emotional impairments after traumatic brain injury (TBI) may substantially impact the learning process of patients with TBI. One could for instance think of a lack of motivation to pursue goals [6], impaired awareness of deficits that impedes participation in rehabilitation [7] or passive coping which hampers active involvement in therapy [8].

The identification of potential barriers for learning would aid clinicians to explore and target these factors in order to facilitate learning in patients with brain injury. This knowledge can provide a starting point for the development of an assessment tool to determine a patient's degree of learning ability. Such a tool may be useful for referring patients to the level of rehabilitation care that best fits their needs and capabilities.

To gain more knowledge about barriers for learning, it is believed it is important to start with exploring clinicians' views and current clinical practice. Therefore, the objectives of this study were to (1) determine whether clinicians take learning ability into account when making a prognosis; 
(2) evaluate clinicians' views on factors influencing learning ability; and (3) determine what assessment tools clinicians currently use to assess a patient's learning ability.

\section{Methods}

\section{Participants and survey}

This study aimed to include the primary disciplines working in brain injury rehabilitation. Therefore, an online survey was sent to members of three major organizations in The Netherlands:

(1) Netherlands Institute of Psychologists (NIP) section rehabilitation psychology (200 members) and section neuropsychology (482 members);

(2) Dutch Working Group of Rehabilitation Physicians for Stroke (40 members); and

(3) National platform for Cognitive Rehabilitation (112 members).

The survey enquired whether clinicians take learning ability into account when making a prognosis. Furthermore, the survey included open-ended questions about factors that can influence a patient's learning ability and about assessment tools respondents use to assess a patient's level of learning ability. In addition, respondents were asked about their age and professional details (profession, years of working experience, type of organization, main patient population).

\section{Statistical analysis}

Mann Whitney U-tests were applied to determine differences between disciplines regarding age and years of working experience. Furthermore, reported assessment tools were categorized into one of the following diagnostic assessment methods: conversation (e.g. intake, anamnesis), observation (standardized and non-standardized), cognitive test(s) or questionnaire(s). Data were analysed using SPSS version 18.0. To adjust for a Type 1 error a Bonferroni correction was applied, alpha was set at $0.05 / 3$ (disciplines) $=0.017$.

\section{Results}

\section{Participants}

In total, 174 rehabilitation professionals replied. The response rate was not calculated given the possibility that some respondents were members of more than one of the three organizations and consequently received the survey more than once. In addition, members of the Netherlands Institute of Psychologists do not necessarily work in a rehabilitation setting, which led them to disregard this survey.

Not all respondents answered all questions. Duplicates $(n=1)$ as well as respondents who did not indicate their profession $(n=10)$ were excluded, leaving a total of 163 respondents. Among these were 37 physicians (36 physiatrists, one psychiatrist), 83 psychologists and 43 therapists (24 occupational therapists, 15 cognitive trainers/therapists, three physical therapists, one psychological assistant). The mean number of years of working experience was 9.0 years $(\mathrm{SD}=6.9$ years; range $=0-29$ years). The mean age of the professionals was 39.4 years $(\mathrm{SD}=9.9$ years; range 22-65 years) (Table I).
Table I. Sample characteristics $(n=163)$.

\begin{tabular}{lc}
\hline Mean age $(\mathrm{SD}), n=162$ & $39.4(9.9)$ \\
Range & $22-65$ \\
Profession, $\%(n)$ & \\
Physician & $22.7(37)$ \\
Psychologist & $50.9(83)$ \\
Therapist & $26.4(43)$ \\
Mean years of experience (SD), $n=147$ & $9.0(6.9)$ \\
Range & $0-29$ \\
Type of organization, $\%(n), n=162^{a}$ & \\
Rehabilitation centre & $73.4(119)$ \\
Hospital & $19.8(32)$ \\
Nursing home & $4.9(8)$ \\
Primary care & $3.7(6)$ \\
Mental healthcare & $2.5(4)$ \\
Main patient population, $\%(n)$ & \\
Adults & $81.6(120)$ \\
Adults and elderly & $10.9(16)$ \\
Children and adults & $4.1(6)$ \\
Children & $3.4(5)$ \\
\hline
\end{tabular}

${ }^{a}$ More than one answer was possible.

A Mann-Whitney U-test with Bonferroni correction revealed that the physicians were significantly older than the psychologists $(\mathrm{U}=798.5, z=-4.19, p<0.0001)$ and the therapists $(\mathrm{U}=466.5, \quad z=-3.05, p=0.002)$. There were no significant differences regarding the number of years of working experience. For the total group, 95.7\% $(n=156)$ spent more than $30 \%$ of their time on neurological patients.

\section{Learning ability and prognosis}

In total, $94.6 \%(n=35)$ of physicians, $91.6 \%(n=76)$ of psychologists and 93\% ( $n=40)$ of therapists indicated that they take learning ability into account when making a prognosis. Reasons for not taking learning ability into account were: everyone has learning ability $(n=1)$; there is no clear definition of learning ability $(n=2)$; learning ability is part of a patient's cognitive functioning $(n=1)$; according to the literature, learning ability is not important $(n=1)$; not involved in making a diagnosis or prognosis $(n=1)$; more environmental adjustments are needed when learning ability is impaired $(n=1)$; and five persons did not specify their answer.

\section{Factors influencing learning ability}

Respondents reported a wide variety of factors influencing learning ability. Thirteen different factors were mentioned by at least five respondents in the total group. Among these were eight psychological factors. Across disciplines, the most frequently mentioned factors were cognition (79.4\%, $n=123)$, awareness of deficits $(56.1 \%, n=87)$ and motivation $(29.0 \%, n=45)$. Furthermore, a considerable number of respondents mentioned injury characteristics $(10.3 \%, n=16)$, pre-morbid functioning $(10.3 \%, n=16)$, personality $(10.3 \%$, $n=16)$ and coping style $(9.7 \%, n=15)$ (Table II).

\section{Assessment of learning ability}

Table III shows that physicians (five out of six) and psychologists (51 out of 54) mainly reported to use cognitive 
Table II. Clinicians' views on factors influencing learning ability. ${ }^{a}$

\begin{tabular}{lcccc}
\hline & Total $(n=155)$ & $\begin{array}{c}\text { Physician }(n=34) \\
\%(n)\end{array}$ & $\begin{array}{c}\text { Psychologist }(n=81) \\
\%(n)\end{array}$ & $\begin{array}{c}\text { Therapist }(n=40) \\
\%(n)\end{array}$ \\
\hline Cognition & $79.4(123)$ & $76.5(26)$ & $81.5(66)$ & $77.5(31)$ \\
Awareness of deficits & $56.1(87)$ & $55.9(19)$ & $54.3(44)$ & $60.0(24)$ \\
Motivation & $29.0(45)$ & $32.4(11)$ & $29.6(24)$ & $25.0(10)$ \\
Injury characteristics & $10.3(16)$ & $8.8(3)$ & $6.2(5)$ & $20.0(8)$ \\
Pre-morbid functioning & $10.3(16)$ & $14.7(5)$ & $8.6(7)$ & $10.0(4)$ \\
Personality & $10.3(16)$ & $5.9(2)$ & $14.8(12)$ & $5.0(2)$ \\
Coping style & $9.7(15)$ & $11.8(4)$ & $12.3(10)$ & $2.5(1)$ \\
Social environment & $5.8(9)$ & 0 & $7.4(6)$ & $7.5(3)$ \\
Ability to generalize acquired skills & $4.5(7)$ & $2.9(1)$ & $3.7(3)$ & $7.5(3)$ \\
Demographic characteristics & $3.9(6)$ & 0 & $4.9(4)$ & $5.0(2)$ \\
Intelligence & $3.9(6)$ & $5.9(2)$ & $3.7(3)$ & $2.5(1)$ \\
Acceptance & $3.2(5)$ & $2.9(1)$ & $2.5(2)$ & $5.0(2)$ \\
Co-operation & $3.2(5)$ & $2.9(1)$ & $3.7(3)$ & $2.5(1)$ \\
\hline
\end{tabular}

${ }^{a}$ Only factors that were mentioned by at least five respondents are reported in the total group.

Table III. Assessment methods of learning ability.

\begin{tabular}{lccc}
\hline Assessment method $^{a}$ & $\begin{array}{c}\text { Physician } \\
\left(n=6^{b}\right)\end{array}$ & $\begin{array}{c}\text { Psychologist } \\
\left(n=54^{b}\right)\end{array}$ & $\begin{array}{c}\text { Therapist } \\
\left(n=17^{b}\right)\end{array}$ \\
\hline Conversation, \% $(n)$ & 0 & $5.6(3)$ & 0 \\
Observation, \% $(n)$ & 0 & $20.4(11)$ & $64.7(11)$ \\
Cognitive test(s), \% $(n)$ & $83.3(5)$ & $94.4(51)$ & $23.5(4)$ \\
Questionnaire, \% $(n)$ & 0 & $5.6(3)$ & $11.8(2)$ \\
Other, \% $(n)$ & $16.7(1)$ & $3.7(2)$ & $29.4(5)$ \\
\hline
\end{tabular}

${ }^{a}$ More than one answer was possible.

${ }^{b}$ Number of respondents that indicated the method of assessment.

tests to determine learning ability, whereas therapists mainly reported to use observational data (11 out of 17). Within these categories, 20 psychologists and nine therapists mentioned specific tests to assess learning ability. The following cognitive tests were mentioned by at least three psychologists: the Rey-Auditory Verbal Learning Test (R-AVLT) [9] $(n=14)$, the Rivermead Behavioural Memory Test (RBMT) [10] $(n=6)$, the Visual Association Test (VAT) [11] $(n=6)$, the Amsterdam Dementia Screening Test 6 (ADS-6): eight word test [12] $(n=4)$ and the Verbal Learning and Memory Test (VLGT) [13]. Therapists mentioned the R-AVLT $(n=1)$ and VLGT $(n=1)$ as well. These five cognitive tests are generally used to assess memory functioning.

Therapists also reported several observational instruments: the Allen Cognitive Level Screen (ACLS) [14] $(n=4)$, the Assessment of Motor and Process Skills (AMPS) [15] $(n=3)$ and the Perceive, Recall, Plan and Perform System (PRPP) [16] $(n=1)$. The AMPS is used to measure instrumental ADL performance, whereas the ACLS and PRPP focus on functional task performance

\section{Discussion}

The vast majority of respondents take learning ability into account when making a prognosis. The most frequently mentioned barriers for learning were cognition, awareness of deficits and motivation. Learning ability was primarily determined by means of cognitive and memory tests and observations during therapy.

Respondents mentioned cognitive functioning, awareness of deficits and motivation as the primary factors influencing a patient's learning ability. Previous studies have also mentioned cognition as an important factor for learning $[2,4]$. One can imagine that relatively intact cognitive functions are essential to grasp and follow instructions and to remember what one has learned. The second factor, awareness of deficits, is important since decreased awareness can reduce the motivation to learn and rehabilitate [17]. In addition, previous studies showed that patients with poor awareness have worse cognitive functioning than patients with good awareness [18, 19]. The third potential barrier to learning is motivation. A patient who is not motivated is unlikely to exert any effort in therapy and in applying the learned skills in daily life [6]. Besides cognition, awareness and motivation, several other factors may indirectly influence learning ability. For example, depression can influence cognitive functioning and motivation [2] and is, thus, indirectly linked to a patient's learning ability.

Ideally, all major potential barriers for learning should be taken into account. However, respondents mainly reported to use cognitive and memory tests and observations during therapy. Regarding the other two potential barriers for learning, motivation and awareness of deficits, no specific tools were mentioned. It is, however, possible that respondents use their observations to estimate a patient's degree of awareness of deficits and motivation. More research is needed to determine whether the mentioned tests are appropriate indicators of learning ability in patients with brain injury.

Several limitations of this study should be noted. Not all respondents answered all questions, which resulted in small group sizes for the question about assessment tools. Furthermore, it is unknown whether the answer 'cognitive tests' refers to the interpretation of test scores for specific cognitive tests or, for example, the observation during the completion of a cognitive test. In addition, for the total group, the years of experience ranged from 0-29 years and is, therefore, a potential confounder in the analysis. Respondents with limited clinical experience may have insufficient knowledge about learning barriers and assessment methods.

However, $73 \%$ of respondents $(n=119)$ had at least 3 years of experience and solely including these patients yielded similar results. A last limitation is that the sample was collected in the Netherlands. Generalizability to other countries may be limited due to differences in healthcare. However, cognitive and physical sequele after ABI are similar 
across countries and, therefore, it is believed that this sample is representative.

In conclusion, the current study is one of the first studies to 'open the black box of learning in rehabilitation' and demonstrates that a patient's learning ability may be influenced by not only cognition but also by motivation and awareness of deficits. Structured and standardized assessment of these factors may be suggested for standard use in clinical practice. More research is needed about the specific influence these factors have on the learning process.

\section{Declaration of interest}

This project is part of the research program Cognitive Rehabilitation, which is funded by the National Initiative on Brain and Cognition in the Netherlands (NWO number 056-11-014). There were no competing interests.

\section{References}

1. Wade DT. Describing rehabilitation interventions. Clinical Rehabilitation 2005;19:811-818.

2. Lezak MD, Howieson DB, Loring DW. Memory I: Tests. In: Lezak MD, Howieson DB, Loring DW, editors. Neuropsychological assessment. 4th ed. New York: Oxford University Press; 2004. p 414-479.

3. Fuhrer MJ, Keith RA. Facilitating patient learning during medical rehabilitation: A research agenda. American Journal of Physical Medicine \& Rehabilitation 1998;77:557-561.

4. Paran D, Litinsky I, Shapira-Lichter I, Navon S, Hendler T, Caspi D, Vakil E. Impaired memory and learning abilities in patients with systemic lupus erythematosus as measured by the Rey Auditory Verbal Learning Test. Annals of the Rheumatic Diseases 2009;68: 812-816.

5. Aadal L, Kirkevold M. Integrating situated learning theory and neuropsychological research to facilitate participation and learning in traumatic brain injury rehabilitation patients. Brain Injury 2011; 25:717-728.

6. Berg I, Deelman B. Herstel en behandeling. In: Deelman B, Eling $\mathrm{P}$, de Haan E, van Zomeren E, editors. Klinische neuropsychologie. 6th ed. Amsterdam, The Netherlands: Uitgeverij Boom; 2004. p 113-128.

7. Leung DPK, Liu KPY. Review of self-awareness and its clinical application in stroke rehabilitation. International Journal of Rehabilitation Research 2011;34:187-195.

8. Ferrari R, Louw D. Coping style as a predictor of compliance with referral to active rehabilitation in whiplash patients. Clinical Rheumatology 2011;30:1221-1225.

9. Rey A. L'examen clinique en psychologie. Paris, France: Presses Universitaires de France; 1941.

10. Wilson BA, Cockburn J, Baddeley AD. The Rivermead Behavioural Memory Test. Bury St Edmunds, UK: Thames Valley Test Company; 1985.

11. Lindeboom J, Schmand B, Tulner L, Walstra G, Jonker C. Visual association test to detect early dementia of the Alzheimer type. Journal of Neurology, Neurosurgery and Psychiatry 2002;73: 126-133.

12. Lindeboom J, Jonker C. Amsterdamse Dementie Screeningstest (ADS 6). Lisse, The Netherlands: Swets \& Zeitlinger; 1988.

13. Mulder JL, Dekker R, Dekker P. Verbale Leer- en Geheugentest. Lisse, The Netherlands: Swets \& Zeitlinger; 1996.

14. Allen CK. Allen Cognitive Level Screen (ACLS) test manual. Colchester, CT: S\&S Worldwide; 2000.

15. Fisher AG. Assessment of motor and process skills. AMPS vol. 2: User manual. 6th ed. Colorado: Three Star Press Inc; 2003.

16. Chaparro C, Ranka J. Research development. The PRPP research training manual. Sydney, Australia: School of Occupational Therapy; 1996.

17. Toglia J, Kirk U. Understanding awareness of deficits following brain injury. NeuroRehabilitation 2000;15:57-70.

18. Noé E, Ferri J, Caballero MC, Villodre R, Sanchez A, Chirivella J. Self-awareness after acquired brain injury. Journal of Neurology 2005;252:168-175.

19. Björkdahl A, Lundgren-Nilsson A, Sunnerhagen KS. How can we tell who is aware? Where does the veracity lie? Journal of Stroke and Cerebrovascular Diseases 2012;21:812-818. 